Article

\title{
Abandoned Mine Tailings Affecting Riverbed Sediments in the Cartagena-La Union District, Mediterranean Coastal Area (Spain)
}

\author{
Tomás Martín-Crespo ${ }^{1, *(\mathbb{C})}$, David Gómez-Ortiz ${ }^{1}\left(\mathbb{D}\right.$, Silvia Martín-Velázquez $^{1}(\mathbb{C}$, \\ Pedro Martínez-Pagán ${ }^{2}{ }^{-}$, Cristina de Ignacio-San José ${ }^{3}$, Javier Lillo ${ }^{1,4}$ and Ángel Faz ${ }^{5}$ \\ 1 Department Biología y Geología, Física y Química Inorgánica, ESCET, Universidad Rey Juan Carlos, \\ C/Tulipán s/n, Móstoles, 28933 Madrid, Spain; david.gomez@urjc.es (D.G.-O.); \\ silvia.martin@urjc.es (S.M.-V.); javier.lillo@urjc.es (J.L.) \\ 2 Department Ingeniería Minera y Civil, Universidad Politécnica de Cartagena, Paseo Alfonso XIII, 52, \\ Cartagena, 30203 Madrid, Spain; p.martinez@upct.es \\ 3 Department Petrología y Geoquímica, Fac. CC. Geológicas, Universidad Complutense de Madrid, \\ C/Antonio Nováis s/n, 28040 Madrid, Spain; cris@geo.ucm.es \\ 4 IMDEA Water Institute, Av/ Punto Com, 2, Parque Científico Tecnológico de la Universidad de Alcalá, Alcalá \\ de Henares, 28805 Madrid, Spain \\ 5 Department Ciencia y Tecnología Agraria, Universidad Politécnica de Cartagena, Paseo Alfonso XIII 52, \\ Cartagena, 30203 Madrid, Spain; angel.fazcano@upct.es \\ * Correspondence: tomas.martin@urjc.es; Tel.: +34-914-888-098; Fax: +34-916-647-490
}

Received: 28 May 2020; Accepted: 23 June 2020; Published: 25 June 2020

\begin{abstract}
This study presents the results of the geoenvironmental characterization of La Matildes riverbed, affected by mine tailings in the Cartagena-La Unión district, Murcia (southeast Spain). Soils and riverbeds in this area are highly polluted. Two Electrical Resistivity Imaging (ERI) profiles were carried out to obtain information about the thickness of the deposits and their internal structure. For the mine tailings deposits of La Murla, a tributary of the El Miedo riverbed, the geophysical method imaged two different units: the upper one characterized by low resistivity values and 5-8 $\mathrm{m}$ thickness, correlated with the mine tailings deposits; and the lower more resistive unit corresponding to the Paleozoic metasediments bedrock. The ERI profile transverse to the Las Matildes dry riverbed revealed the existence of three different units. The uppermost one has the lowest resistivity values and corresponds to the tailings deposits discharged to the riverbeds. An intermediate unit, with intermediate resistivity values, corresponds to the riverbed sediments before the mining operations. The lower unit is more resistive and corresponds to the bedrock. Significant amounts of pyrite, sphalerite, and galena were found both in tailings and riverbed sediments. The geochemical composition of borehole samples from the riverbed materials shows significantly high contents of As, $\mathrm{Cd}, \mathrm{Cu}, \mathrm{Fe}, \mathrm{Pb}$, and $\mathrm{Zn}$ being released to the environment. Mining works have modified the natural landscape near La Unión town. Surface extraction in three open-pit mines have changed the summits of Sierra de Cartagena-La Unión. Rock and metallurgical wastes have altered the drainage pattern and buried the headwaters of ephemeral channels. The environmental hazards require remediation to minimize the environmental impact on the Mar Menor coastal lagoon, one of the most touristic areas in SE Spain.
\end{abstract}

Keywords: riverbed; metals; electrical resistivity imaging; tailings; Mar Menor; Cartagena-La Unión 


\section{Introduction}

The Province of Murcia, situated in the southeastern most part of the Iberian Peninsula, is one of those mining areas in Spain that today still suffer from serious environmental problems due to the presence of nearly eighty abandoned mineral waste structures, especially in the Sierra de Cartagena area and La Unión town [1]. A large amount of mine wastes was abandoned up until the 1980s, representing serious geochemical hazards. The composition and emplacement sites of these mine wastes have generated environmental hazards related to geochemical pollution (among others), that negatively affect soils, groundwater, flora, fauna, and humans [1,2]. It is therefore necessary to gain deeper knowledge of the current condition of these deposits with high potential risk. There are examples of studies on tailings ponds using (i) magnetometry, enabling us to deduce the variations of the tailings structures [3,4]; (ii) electromagnetics, used to investigate the structural and hydrogeological settings of oil sands tailings dykes [5]; (iii) seismic, to derive the internal pond boundaries by means of refraction and reflection waves [6,7]; and direct-current geoelectrical imaging surveys [8], where the electrical resistivity tomography (ERI) method is strongly affected by the variation of some important properties of tailings such as moisture, soil salinization, particle size distribution, acid mine drainage, etc. $[9,10]$. The ERI method has been the fundamental tool to support physical-chemical analysis in phytoremediation works on the abandoned mining ponds in the Sierra de Cartagena area. The application of geophysical, mineralogical, and geochemical techniques, together with landscape evolution studies, could allow the analysis and quantitative assessment of the pollution risk [11-15].

This work presents the results obtained by the joint application of geophysical, mineralogical, and geochemical techniques to both mine tailings and riverbed sediments from Las Matildes (Cartagena-La Unión district, Murcia, SE Spain). The shallow non-destructive geophysical technique applied in the study was electrical resistivity imaging. To gain better control of the geophysical results, aerial photographs of the area from different times have been used to evaluate the changes in relief that have progressively occurred due to the tailings accumulation. Geochemical and mineralogical characterization techniques include X-ray diffraction, Inductively Coupled Plasma Mass Spectrometry (ICP-MS), and Atomic Absorption Spectroscopy (AAS). Thus, a representative characterization of the riverbed affected by mine tailings has been established based on the geometry and internal structure of deposits, mineralogical and chemical composition, and thickness of tailings and alluvial sediments. Besides the high levels of contamination in abandoned mine sites, the land surface is intensely transformed. The transfer of huge amounts of earth causes the destruction of natural landscapes and the formation of new landforms. As these new environments are also modelled by earth surface processes (involving water, wind, mass movement), different studies have recently focused on geomorphic changes due to mining activity $([16,17]$ and references therein). In the area of $100 \mathrm{~km}^{2}$ of the Sierra de Cartagena-La Unión mining district, 12 open-pits and 2351 waste deposits from ore-processing have been documented [1]. Some of these residues are in the headwaters of ephemeral channels to the east of La Unión town. To identify the geomorphic changes through time in this area, we have mapped the main mining wastes and excavations by means of aerial photograms, orthoimages, and anaglyphs from 1956 and 2016. The temporal evolution has also been used to evaluate landscape changes at the two survey sites and gain better control of the geophysical results.

Thus, the main objective of this study was to characterize the present conditions of tailings and riverbed sediments to identify potential environmental problems. This part of SE Spain is still highly polluted because the numerous mine wastes and mining structures (buildings, shafts, ... ) remain abandoned. The goal is particularly relevant as this situation provokes a continual flow of Acid Mine Drainage (AMD) with associated metal pollution of soils and waters that are dispersed to the Mediterranean Sea.

\section{Location and Features of the Mine Site}

The mine tailings area studied is located around $1 \mathrm{~km}$ to the east of the town of La Unión (SE Spain) (Figure 1). The Descargador mine pond is located just on a tributary of the El Miedo ephemeral 
riverbed and shows maximum dimensions of $180 \mathrm{~m} \times 30 \mathrm{~m}$. The mine tailings are flotation deposits of medium-to-fine-grained, sand-size material. They were produced from grinding and metallurgical processing of pyrite, sphalerite, and galena from the Emilia mine, in works carried out between 1952 and 1981 [18,19]. The main ore minerals are pyrite, sphalerite, galena, and cassiterite. Other minor sulfides include chalcopyrite, minerals of the tetrahedrite-tenantite group, and arsenopyrite. Gangue minerals include chalcedony, quartz, siderite, and greenalite $[20,21]$.
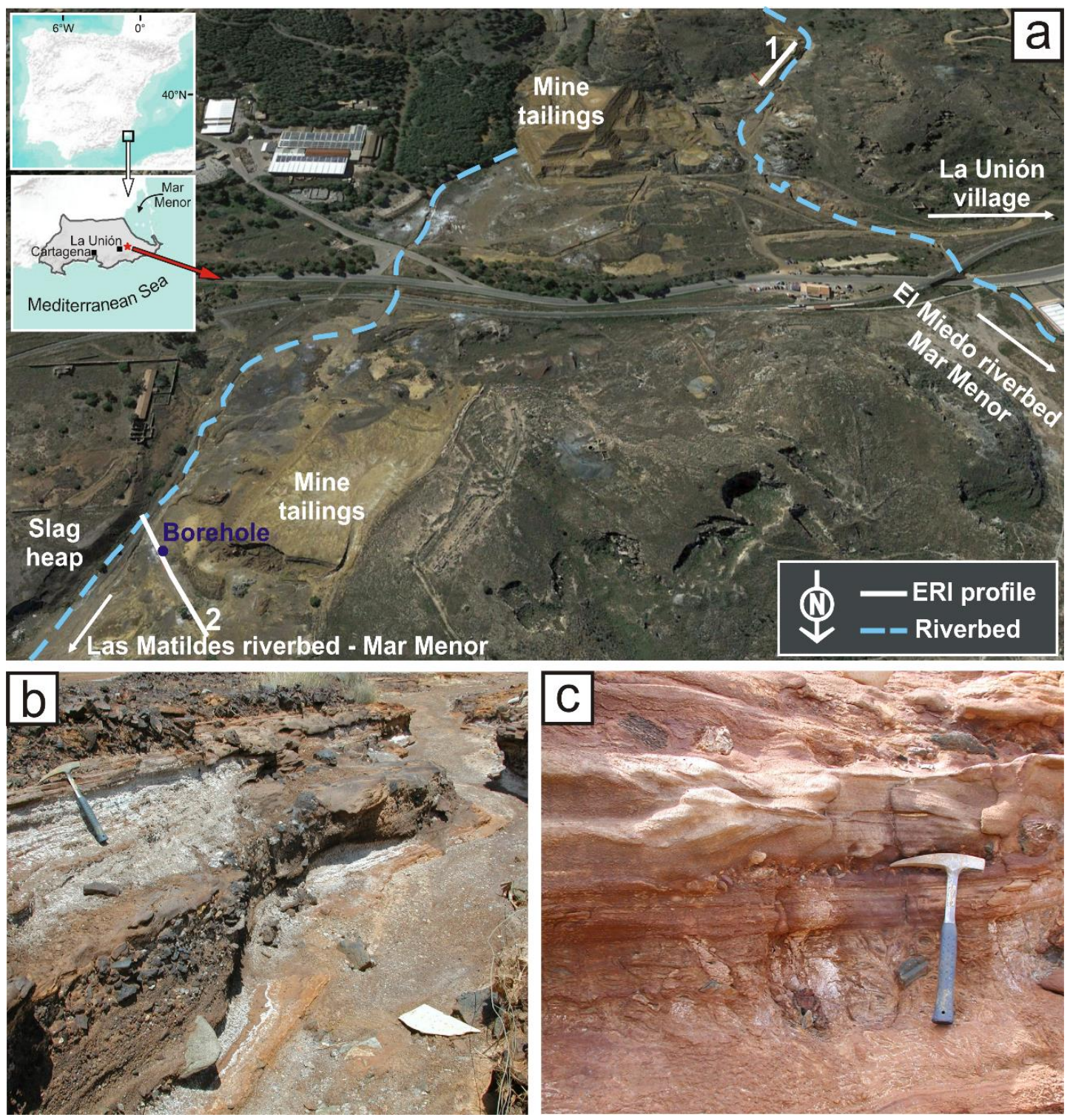

Figure 1. (a) Location of the Cartagena-La Unión mine district, the geophysical surveys, and the sampling points; (b) mine tailings and metallurgical slag, mixed with riverbed sediments in the Las Matildes riverbed; (c) remaining medium-to-fine-grained mine tailings deposits, showing embedded metamorphic bedrock fragments.

This mine pond was placed on Palaeozoic schists, gneisses, and metabasites from the so-called "Complejo Nevado-Filábride" of the Betic Cordillera, and the riverbed ran upon limestone and phyllites from the "Complejo Alpujárride" of the same Cordillera. In this area, significant amounts (tonnes) of metallurgical slag were dumped in ponds over the riverbed sediments. The Las Matildes riverbed is an ephemeral watercourse running from the Descargador area to the Mediterranean Sea. Both ephemeral rivers flow into the Mar Menor coastal lagoon. The Mar Menor is one of the largest hypersaline 
coastal lagoons of the Mediterranean Area, measuring about $170 \mathrm{~km}^{2}$ with a mean depth of $2.5 \mathrm{~m}$. It is separated from the Mediterranean Sea by a narrow sandy coastal barrier and is surrounded by the Campo de Cartagena, one of the most intensive agricultural zones of Spain. This fragile ecosystem suffers intense human pressure, such as excess nutrient and sediment inputs from agriculture and abandoned mining activities, respectively, as well as decreases in salinity.

The region is characterized by a semiarid Mediterranean climate with dry summers and mild winters [22,23]. According to data collected by the closest and most complete automatic weather station of the Agricultural Information System of Murcia (La Aljorra, 2000-2016 period; [24], the mean annual temperature was $18{ }^{\circ} \mathrm{C}$, with a minimum in January $\left(-2{ }^{\circ} \mathrm{C}\right)$ and a maximum in July $\left(41^{\circ} \mathrm{C}\right)$. Rainfall was extremely variable, with intense storms in October and September (maximum rainfall event in a $24 \mathrm{~h}$ period of $163 \mathrm{~mm}$ ). Due to the low precipitation (annual average of $279 \mathrm{~mm}$ ) and high evapotranspiration (annual average from the Penman-Monteith method: $1368 \mathrm{~mm}$ ) only ephemeral streams that drain into the Mar Menor coastal lagoon during heavy rainfalls exist. The area is subjected to strong annual stormy episodes that can induce significant flash flooding. As an example of these episodes, in October 1972, an extremely intense rainfall event caused a flash flood of the tailings from the Brunita mine pond, located only $2 \mathrm{~km}$ to the west of the studied area, killing one person and causing serious material damage [14,25].

\section{Methodology}

\subsection{Temporal Evolution of the Mining Landscape}

This study focused on an area of $\sim 4 \mathrm{~km}^{2}$ to the east of La Unión town, where numerous mining works extend along the small headwaters of the El Miedo and Las Matildes dry riverbeds in the Sierra de Cartagena-La Unión region. The geophysical and geochemical survey was conducted in deposits located in both riverbeds. The mountain range (Sierra) extends $\sim 26 \mathrm{~km}$ from east to west, parallel to the Mediterranean coast. The headwater tributaries transport sediments under torrential rainfall from the highest peak (Sancti Spiritus 3, $396 \mathrm{~m}$ ) to the Mar Menor lagoon, $\sim 8 \mathrm{~km}$ away to the North.

Main fluvial channels, mining wastes (rock and slag dumps, tailings ponds), and mining excavations (canals, open-pit mines) were mapped by using orthoimages from the years 1956 and 2016 using ArcMap 10.4.1 (GIS software, ESRI España Soluciones Geoespaciales, S.L.: Madrid, Spain). The orthoimages were added from the cartography service of the Murcia Region (https://geoportal. imida.es/gis/rest/services/2_03_ORTOIMAGENES). Aerial photograms from 1956 (USA Army Map Service flight-Geographic Service of the Spanish Army, scale of 1:32,000) were used to distinguish landscape changes by means of a stereoscope. The stereo pairs were downloaded from the IGN website (Instituto Geográfico Nacional, https://fototeca.cnig.es/). Regarding the 2016 orthoimage (IGN flight), an anaglyph was checked in the cartographic viewer of IGN (https://www.ign.es/iberpix2/visor/) with a 3D red cyan glass.

\subsection{Non-Destructive Geophysical Method}

Electrical resistivity imaging (ERI) is a shallow geophysical prospecting method designed to unravel complex geological structures with changes in both vertical and horizontal resistivity. The fundamentals of the resistivity methods can be found in different reviews [8,26-29]. The method implies the use of a variable number of electrodes, typically between 24 and 96, connected to a switching box via a multi-core cable [30]. The electrodes are switched to obtain measurements of subsurface resistivity at different depths. By means of a computer connected to the resistivity meter, different combinations of four electrodes are selected automatically for each measurement. By using different electrode spacing at different locations along the cable, a 2-D profile of the subsurface is finally obtained (e.g., [8]). As a rule of thumb, it is important to note that the measurements for each quadripole provide values of apparent resistivity at different depths, in such a manner that the greater the spacing between the electrodes, the deeper the depth of investigation. A Syscal Junior Switch 48 equipment 
was used in this work. The number of electrodes is 48 with a maximum electrode spacing of $5 \mathrm{~m}$. This equipment uses an injection cycle of $4 \mathrm{~s}$ with an output voltage of up to $400 \mathrm{~V}$ and rejection filters for 50 and $60 \mathrm{~Hz}$. Noise reduction is obtained by applying a continuous stacking selectable from 1 to 255 stacks. With these parameters, an average value (and the associated level of uncertainty) of the apparent resistivity is obtained for each quadripole. For the geolocation of the profiles, a MAGELLAN MobileMapper CX GPS with a submetrical accuracy has been used.

After the acquisition of the apparent resistivity values, the data must be processed to remove spurious data points. This is done by filtering raw data with low signal values $(\mathrm{V} / \mathrm{I}<10-6 \Omega)$ or repeatability errors greater than $2 \%$. In addition to this, topography data for each electrode of the profile must also be included at this stage. Once filtered, an iterative inversion process must be carried out to obtain a cross-section of true resistivity along the survey's profile. The code selected to iteratively convert the apparent resistivity values to true resistivity values is RES2DINV, which uses the L1 norm for the data misfit and the inversion is performed using the L1 norm (robust) for the model roughness filter [31]. A robust inversion has been chosen because this kind of inversion is more accurate when sharp discrete boundaries exist in the model. In the study area, sharp boundaries exist between the high resistive metamorphic rocks constituting the basement and the low resistive loose materials that define both the mine pond and dry riverbed infilling, so robust inversion is the most appropriate choice. The method uses a finite element scheme for solving the 2-D forward problem and blocky inversion method for inverting the ERI data [31]. The result of the process is a true resistivity image for each profile that is used to obtain the final interpretation of the variations of the subsurface lithology.

Regarding the application of electrical techniques for the characterization of mine waste deposits, good examples can be found in [32,33]. The ERI technique has mainly been used on waste piles [34] and tailings dams [35], whereas few studies have focused on the internal structure of mine tailings ponds (e.g., [2,11-14,36-39]). To combine a good penetration depth, a reasonable vertical and horizontal resolution, and a good signal-to-noise ratio, the Wenner-Schlumberger array was chosen for this study. This array has been successfully used in similar studies (e.g., [2,14]).

\subsection{Description of Sampling Methods}

In the Las Matildes dry riverbed, sequential sampling was carried out using a TP-50/400 rotary drilling machine, with a minimum core bit diameter of $100 \mathrm{~mm}$ (Figure 1). Non-disturbed rock drill core samples were collected with a constant vertical spacing of $50 \mathrm{~cm}$, up to a sampling depth of $8 \mathrm{~m}$. This sampling was carried out by digging down below the surface of each pond, casting aside the parts corresponding to surficial sealing to prevent wall material falling during drilling. In total, 17 unaltered samples (five from the borehole, 11 from the ponds and one from the bedrock) were collected, air-dried for 7 days, passed through a 2-mm sieve, homogenized, and stored in plastic bags at room temperature prior to laboratory analyses. Sampling was conducted in March.

\subsection{Mineralogical and Geochemical Methods}

Mineralogical characterization of samples was performed by X-ray diffraction (XRD) using a Philips $X^{\prime}$ Pert powder device with a $\mathrm{Cu}$ anticathode and standard conditions: speed $2^{\circ} 20 /$ min between $2^{\circ}$ and $70^{\circ}$ at $40 \mathrm{~mA}$ and $45 \mathrm{KV}$. The whole sample was studied by crystalline non-oriented powder diffraction on a side-loading sample holder. Semi-quantitative results were obtained by the normalized reference intensity ratio (RIR) method. The XRD analyses were performed at the Centro de Apoyo Tecnológico (CAT Universidad Rey Juan Carlos, Móstoles, Spain, http://www.urjc.es/cat). From the total list of major, minor and trace elements analyzed, 12 were chosen for the geochemical study ( $\mathrm{Ag}, \mathrm{As}, \mathrm{Cd}, \mathrm{Cr}, \mathrm{Cu}, \mathrm{Fe}, \mathrm{Ni}, \mathrm{Pb}, \mathrm{S}, \mathrm{Sb}, \mathrm{Sn}$ and $\mathrm{Zn}$ ) owing to their abundance in these types of sludge and also because most of them are included in the priority contaminant list of the environmental protection agencies [40]. The selected elements were analyzed by TD (Total Digestion) or FUS (lithium metaborate/tetraborate fusion) ICP-MS (Inductively Coupled Plasma-Mass Spectrometry) at Activation Laboratories Ltd. (1428 Sandhill Drive, Ancaster, Ontario, Canada; http://www.actlabs.com). Quality 
control at Actlabs is done by analyzing duplicate samples and blanks to check precision, whereas accuracy is ensured by using Certified Reference Materials (GXR series; see http://www.actlabs.com). Detection limits for the analyzed elements are (data in $\mu g . g^{-1}$ ): Ag (0.3), As (5), Cd (0.5), Cr (20), $\mathrm{Cu}$ (1), Fe (100), Ni (1), Pb (5), S (10), Sb (0.5), Sn (1), and $\mathrm{Zn}$ (1). Concentrations of Pb $>5000$ and $\mathrm{Zn}>10000 \mu \mathrm{g} \cdot \mathrm{g}^{-1}$ (above the ICP-MS maximum detection limits) were measured by an Atomic Absorption Spectrometer (AAnalyst 800, Perkin Elmer spectrometer) using flame or graphite-furnace technique in the Universidad Politécnica de Cartagena (Murcia, Spain) laboratories. pH was measured using an electronic $\mathrm{pH}$ meter (CRISON), calibrated at two points ( $\mathrm{pH} 7$ and $\mathrm{pH} 4)$ using standard buffer solutions. This parameter was determined in a slurry system with an air-dried sample (10 g) mixed with distilled water $(25 \mathrm{~mL})$. Before reading the $\mathrm{pH}$ values, the mixture was vigorously stirred in a mechanical shaker for $10 \mathrm{~min}$ and left to stand for $30 \mathrm{~min}$.

Statistical data processing was done using Minitab 17 software (Minitab Ltd., Brandon Court, Unit E1-E2, Progress Way, Coventry CV3 2TE, United Kingdom). The multivariate analysis was based on clustering (group average linkage dendrograms, Euclidean distance) of the set of samples and significant metals ( $\mathrm{Ag}, \mathrm{Sb}, \mathrm{Fe}, \mathrm{Cd}, \mathrm{Cu}, \mathrm{Pb}, \mathrm{Zn}$, and $\mathrm{Sn}$ ) plus As.

\section{Results and Discussion}

The landscape evolution in a sector of the La Union mining district, as well as the results of the geophysical study concerning the structure of the tailings and riverbed, and those obtained from mineralogical and geochemical characterization of the borehole samples, are presented and discussed here.

\subsection{Temporal Evolution of Mining Landscape of La Union}

In the 1956 orthoimage (Figure 2), the orography to the E of La Unión consisted of N-S to NNW-SSE V-shaped valleys with headwaters in Sancti Spiritus hill (431 m: [41]). The westernmost one, the La Murla riverbed ( $~ 900 \mathrm{~m}$ long), is a tributary of the El Miedo riverbed, whereas the rest (average length of $\sim 600 \mathrm{~m}$ ) are tributaries of the Las Matildes riverbed. Some works related to underground mines are recognized in the southern slopes of Sancti Spiritus. The first operations at the Emilia open pit mine are visible at the easternmost tributary headwater. However, the most important modifications occur on the northern slopes of Sancti Spiritus where many waste residues are scattered over valley bottoms and foothills. The mapped deposits originated to a certain extent by rock accumulations from open-pits and mines and mainly from waste accumulation during metallurgical processes (slag dumps from melting and tailings heaps from the post-flotation process); 35 rock and slag dumps and the five tailings dams occupy an area of $\sim 0.4 \mathrm{~km}^{2}$ and modified some hydrological pathways. Several slag deposits abruptly changed the courses of Las Señales, El Humo, and La Hoya del Agua riverbeds, and a tailings dam interrupted the flow of La Hoya del Agua tributary. Therefore, two canals had to be built to evacuate surface runoff.

Geomorphic changes mapped in the 2016 orthoimage (Figure 2) are mostly related to the movement of huge rock volumes from the open pit of Emilia, San Valentín, and Tomasa. The mineral extraction from San Valentín and Tomasa mines completely changed the summit orography in Sancti Spiritus hill (Santi Spiritus 3, 396 m: [42]). At present, the open-pit mines are partially filled with wastes from metallurgical, building, and industrial activities [1]. Another profound transformation is associated with the growth of open-pit spoils in the vicinity of mines, which buried the Las Señales and El Humo headwaters as well as the channel of La Hoya del Agua and its tributaries. Residues from mineral treatment accumulated in the previous tailings dams located in La Murla and Las Señales riverbeds, increasing their sizes, but also in Las Matildes riverbed. Furthermore, these younger materials buried previous polluted residues wastes (see, for example, the area of the open-pit spoils to the west of Emilia mine, or the tailings dams in Las Matildes riverbed). Regarding the slags, some dumps are smaller because they were excavated. The area of mine deposits ( 21 rock and slag dumps and 10 tailings ponds) on the 2016 image is $\sim 0.8 \mathrm{~km}^{2}$, two times larger than that in 1956 . 

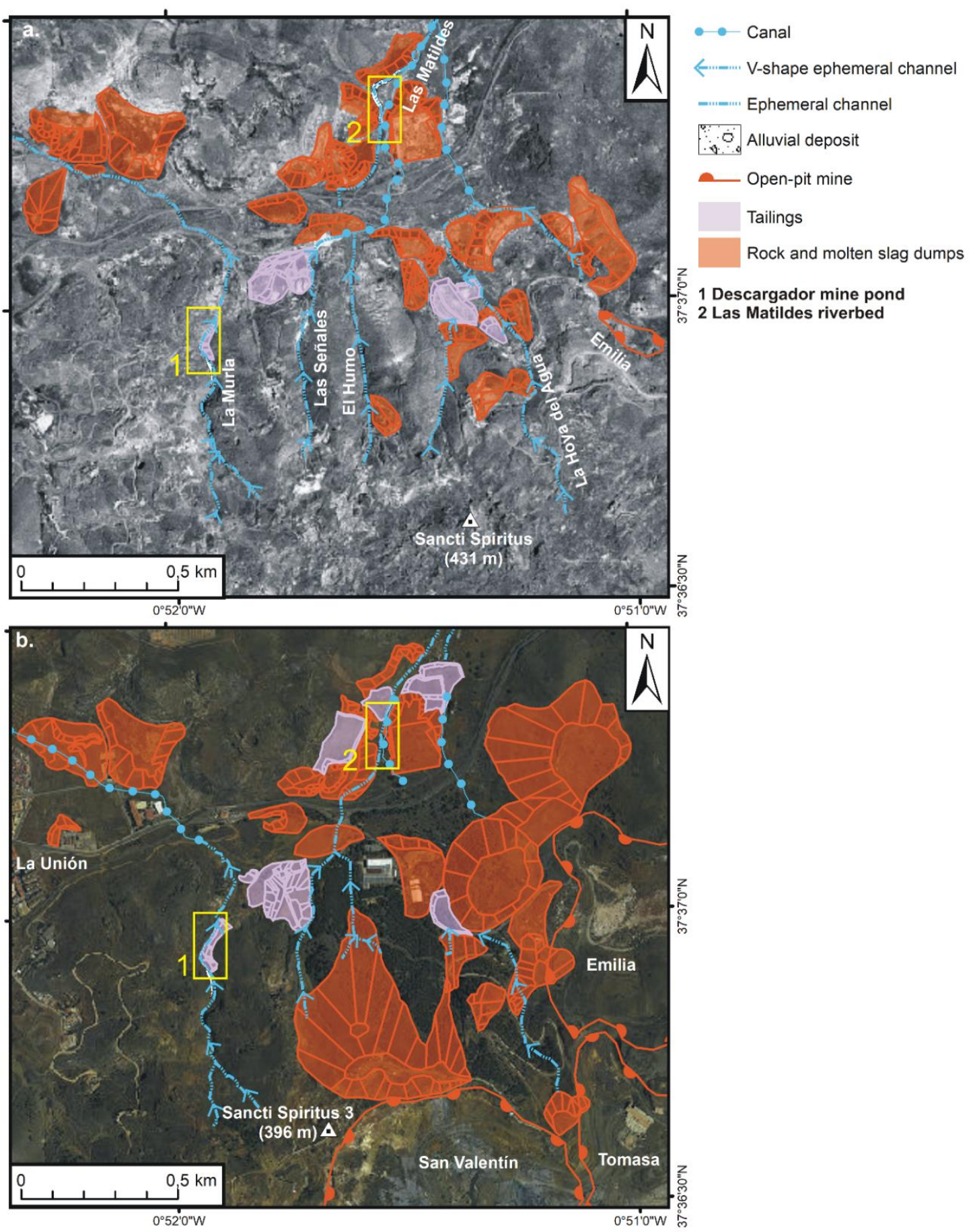

Figure 2. Mapping of the temporal evolution of the mining landscape to the east of La Unión town: (a) orthoimage from 1956 (Cartography Service of the Murcia Region); (b) orthoimage from 2016 (Cartography Service of the Murcia Region). Yellow rectangles: areas where geophysical prospection has been carried out: 1. Descargador mine pond, and 2. Las Matildes riverbed.

The temporal evolution of the mining works explains the geophysical results (Section 4.2) and the stratigraphic sequence of the core samples collected from Las Matildes riverbed (Section 4.3). Sludge in the Descargador mine pond in the La Murla valley was initially deposited in the riverbed (Figure 2a). However, due to the continued discharge, the tailings dam was raised over the metamorphic rocks of the foothill (Figure 2b). The uppermost material at the Las Matildes site, identified both in the borehole and the geophysical surveys, is related to the tailings deposit mapped in the riverbed in the 
2016 orthoimage (Figure $2 b$ ). This mining waste overlapped the alluvial sediments that were identified in the 1956 orthoimage (Figure 2a). The intensive mining activities have deeply affected the landscape in this sector of the Sierra de Cartagena-La Unión. Open-pit mines and mining and metallurgical residues disrupted the natural fluvial network; furthermore, new canals were created to evacuate surface runoff. Polluted waste that accumulated in riverbeds and foothills as colluvium and alluvium sediments can be eroded and therefore mobilized by mass movements and surface runoff. The volume of tailings in the three largest dams has reached $623,000 \mathrm{~m}^{3}$ [19].

Particulate and dissolved contaminants move from the anthropic deposits along the El Miedo and Las Matildes ephemeral riverbeds to the Mar Menor lagoon. Indeed, high concentrations of $\mathrm{Pb}$ and $\mathrm{Zn}$ have been measured in the sediments of the nearby El Beal riverbed (mean values of 39,000 and 2000 ppm, respectively: [1]). Therefore, the environmental impact of modified landscapes should also be considered, both in the estimation of potential risk, and in the proposal of management and reclamations solutions [17].

\subsection{Structure of the Mine Pond and Riverbed Deposits}

ERI has provided information about both the thickness and geometry of the waste deposits related to the mine tailings. Two ERI profiles have been carried out (one longitudinal to the mine pond and one transverse to the watercourse) (Figure 1). The borehole provided (from top to bottom) thicknesses of $2 \mathrm{~m}$ of mine tailings, $1.5 \mathrm{~m}$ of tailings mixed with riverbed sediments, and $4 \mathrm{~m}$ of riverbed sediments.

\subsubsection{Mine Pond}

The ERI profile (Figure 3) imaged two different units: the upper one is characterized by low resistivity $(<20 \mathrm{ohm} \cdot \mathrm{m})$ values and a thickness ranging from $5-8 \mathrm{~m}$. It can be correlated with the mine tailings deposits observed at the outcrop (Figure 1). In contrast, the lower unit is more resistive $(>200 \mathrm{ohm} \cdot \mathrm{m})$ and corresponds to the Paleozoic metasediments that constitute the bedrock of the area.
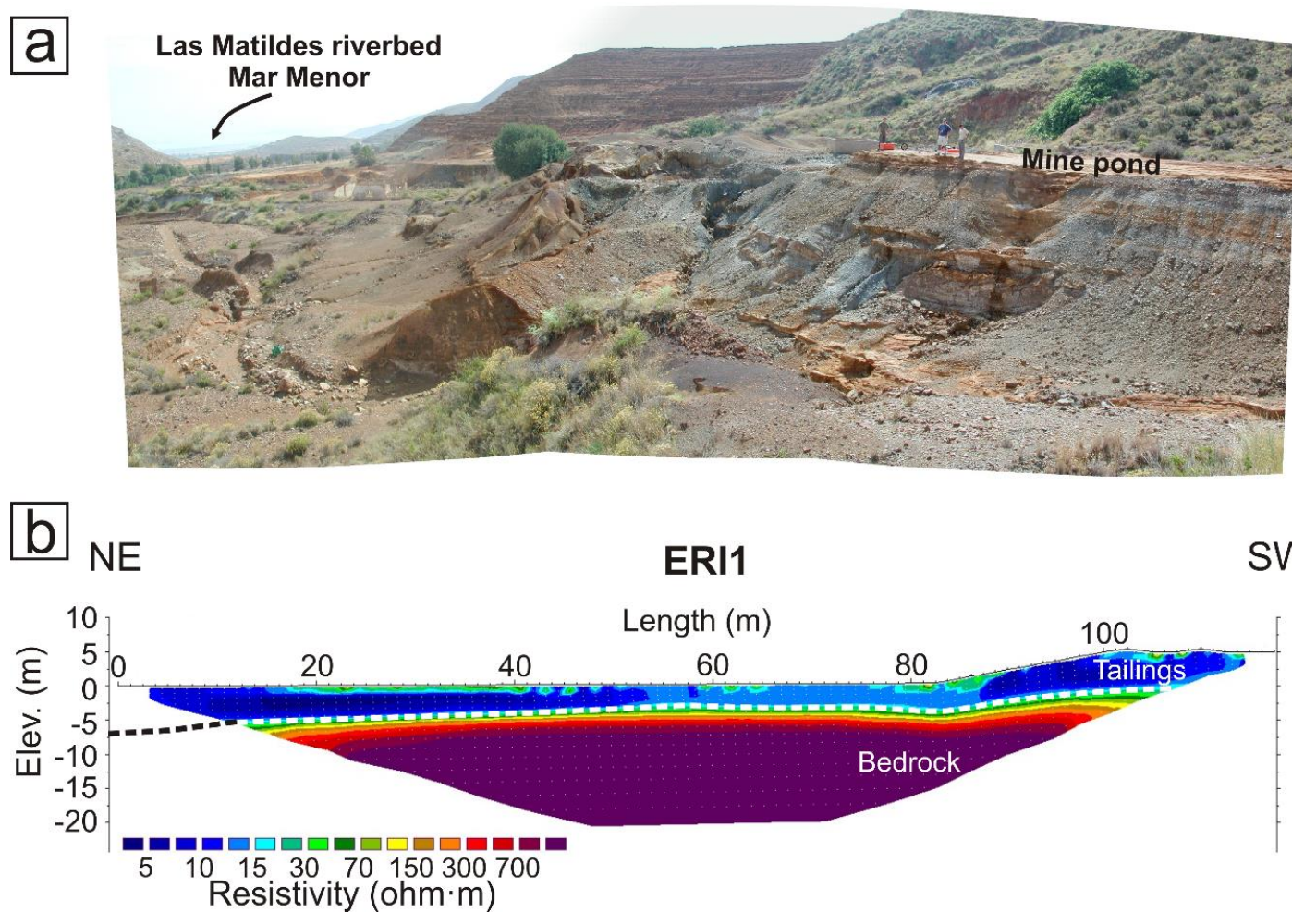

Figure 3. Descargador mine pond: (a) general view of the non-eroded remaining tailings; (b) ERI profile showing the two identified units. 
As can be seen in the profile, the bedrock below the mine pond deposits is very homogeneous and consequently, the occurrence of faults or discontinuities can be disregarded. The ERI profile does not have enough lateral and vertical resolution to discriminate different units inside the mine pond deposits. Extremely low resistivity values characterize the occurrence of AMD inside the mine ponds, as demonstrated in nearby similar areas (e.g., Brunita mine pond, [14]), or even different mine districts (e.g., Mina Concepción, [15]). In Mina Concepción, values lower than $5 \mathrm{ohm} \cdot \mathrm{m}$ delineate the preferential path of AMD ( $\mathrm{pH}$ ranging from 2.5 to 3 ) flow inside the mine ponds. In the case of Descargador mine pond, the low (5-20 $\mathrm{ohm} \cdot \mathrm{m})$ resistivity values measured in the mine pond infilling are compatible with the clayish to sandy-clayish texture and high water content of the deposits, as observed in the field, and thus internal AMD flow can be disregarded. A certain acidic character of the water ( $\mathrm{pH}$ 5-6) has been obtained for the same resistivity values in similar mine ponds (e.g., San Quintin mine pond, [15]) and this would be the case here. Moreover, the highly homogeneous and resistive character of the metamorphic bedrock imaged below the mine pond allows us to confirm that there is no AMD flow escaping from the bottom of the mine pond that could be affecting the groundwater of nearby fractured aquifers.

\subsubsection{Dry Riverbed}

The ERI profile transverse to the dry riverbed (Figure 4) has revealed the existence of three different units whose interpretation has been made by comparing them with the borehole data. The uppermost one, with a mean thickness of 2-3 m, extends from 21 to $100 \mathrm{~m}$ along the profile and has the lowest resistivity values $(<15 \mathrm{ohm} \cdot \mathrm{m})$. It corresponds to the tailings deposits transported episodically by the riverbed during periods of strong rainfall. An intermediate unit, with resistivity values ranging from 15 to $40 \mathrm{ohm} \cdot \mathrm{m}$ and varying thickness ( 1 to $4 \mathrm{~m}$ ), corresponds to the watercourse sediments before the construction of the mine tailings pond located upstream. The lower unit is more resistive $(>50 \mathrm{ohm} \cdot \mathrm{m})$ and corresponds to the bedrock.
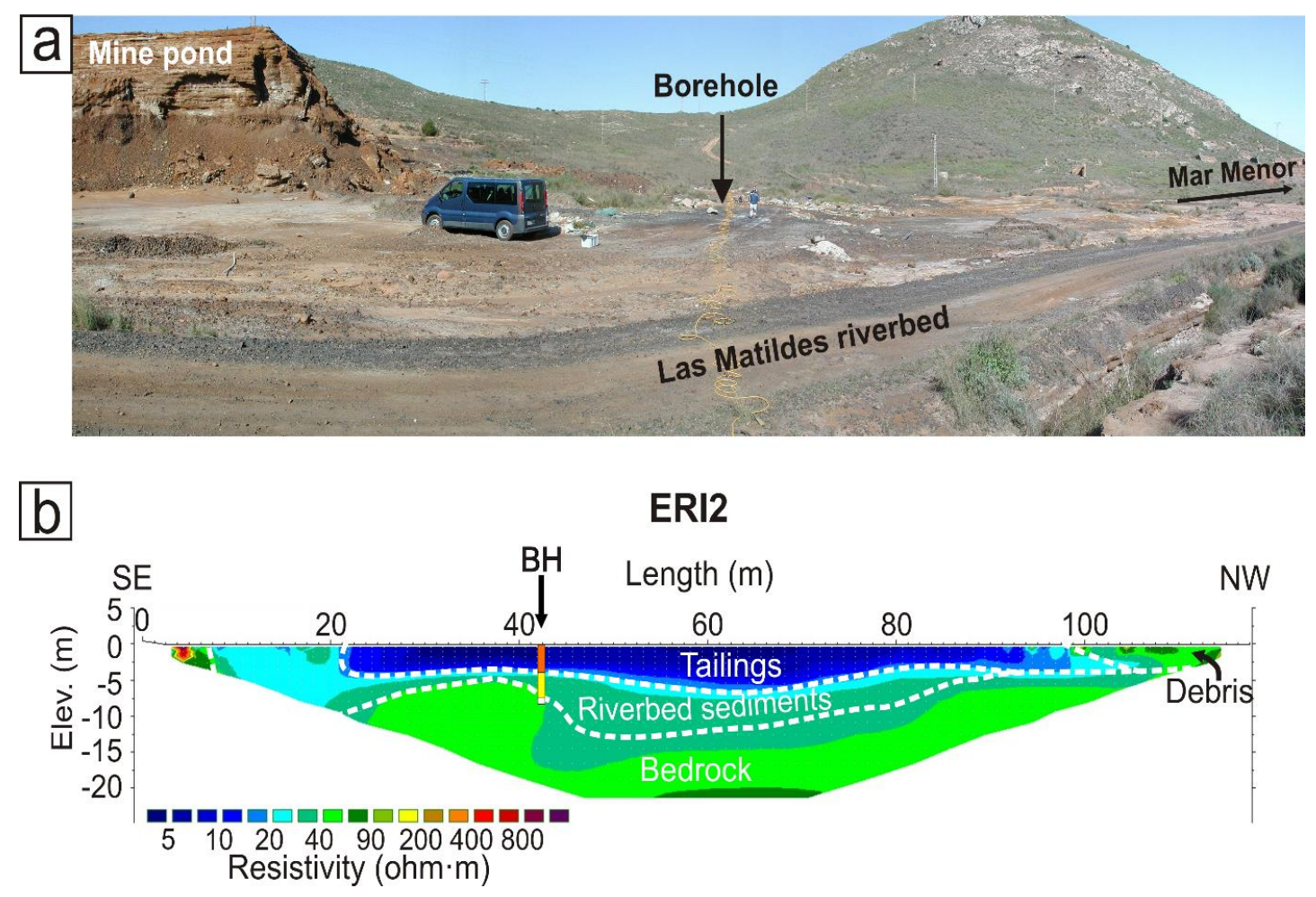

Figure 4. Las Matildes riverbed: (a) general view with borehole location; (b) ERI profile showing the three identified units; $\mathrm{BH}$ : borehole. 
Two small heterogeneous highly resistive $(>200 \mathrm{ohm} \cdot \mathrm{m})$ units located at both ends of the profile can be associated with debris deposits from the neighboring slag heap. As for the Descargador mine pond, the resistivity values observed at the uppermost unit $(5-15 \mathrm{ohm} \cdot \mathrm{m})$ are not low enough to infer that AMD flow occurs in the transported tailings deposits. The mean $\mathrm{pH}$ value obtained from the borehole samples is close to 5, confirming the slightly acidic character of the deposits but far from the extremely low $\mathrm{pH}$ values of $\sim 2.5$ typical of AMD observed in similar deposits, as previously cited. The EC values obtained from the borehole samples, although greater than the intermediate and lower units (3-8 mS/cm vs. $0.2-3 \mathrm{mS} / \mathrm{cm}$ ) are also very far from the extremely high EC values $(>8000 \mathrm{mS} / \mathrm{cm}$ ) obtained in the nearby Brunita mine pond where AMD flow has been detected [14]. For the intermediate unit, the measured $\mathrm{pH}$ values are higher than 6 , in good agreement with the higher resistivity values and coarse texture of the deposit that characterizes this unit. No evidence of faulting or AMD can be observed in the lower resistive unit corresponding to the bedrock.

\subsection{Mineralogical Characterization}

The semi-quantitative data on the mineralogical composition of the Las Matildes samples from the borehole $(\mathrm{BH})$ are displayed in Table 1.

Table 1. Semi-Quantitative Mineralogical Composition (wt \%) of the Studied Samples from the Las Matildes Riverbed Borehole. Qtz: Quartz, Ill-kn: Illite-Kaolinite; Chl: Chlorite; Gre: Greenalite; Py: Pyrite; Sp: Sphalerite; Gn: Galena; Ang: Anglesite; St: Stannite; Ja: Pb-Jarosite; Sd: Siderite; Gp: Gypsum. Groups of Samples: Tailings, Tailings and Riverbed Sediments $(\mathrm{T}+\mathrm{S})$, Riverbed Sediments, and Bedrock (R).

\begin{tabular}{|c|c|c|c|c|c|c|c|c|c|c|c|c|c|c|}
\hline Sample & & Depth (m) & Qtz & Ill-kn & Chl & Gre & Py & $\mathrm{Sp}$ & $\mathrm{Gn}$ & Ang & St & $\mathrm{Ja}$ & Sd & $\mathrm{Gp}$ \\
\hline MAT-1 & & 0 & 30 & 10 & 5 & $1-5$ & 10 & 10 & 5 & 5 & & 5 & 5 & 15 \\
\hline MAT-2 & $\infty 0$ & 0.5 & 30 & 10 & 10 & & 5 & 10 & 5 & 5 & & 5 & 5 & 15 \\
\hline MAT-3 & $\Xi$ & 1 & 30 & 10 & & $1-5$ & 5 & 5 & 5 & 5 & 5 & 15 & 5 & 15 \\
\hline MAT-4 & ] & 1.5 & 25 & 5 & & & 5 & 10 & $5-10$ & 5 & 5 & 15 & 5 & 15 \\
\hline MAT-5 & & 2 & 25 & 5 & & 5-10 & & 5 & $5-10$ & $1-5$ & 5 & 15 & 5 & 15 \\
\hline MAT-6 & $\infty$ & 2.5 & 40 & 15 & 5 & 10 & 5 & 5 & $5-10$ & 10 & & & & 5 \\
\hline MAT-7 & + & 3 & 45 & 10 & 5 & $1-5$ & 5 & 5 & 5 & 10 & & & & 10 \\
\hline MAT-8 & $E$ & 3.5 & 45 & 10 & 5 & $1-5$ & 5 & $1-5$ & & 10 & & & & 15 \\
\hline MAT-9 & $\infty$ & 4 & 50 & 20 & & 5 & 5 & 5 & & 10 & & & & 5 \\
\hline MAT-10 & E्త & 4.5 & 55 & 20 & $1-5$ & 5 & 5 & & & 10 & & & & \\
\hline MAT-11 & $\mathscr{\Xi}$ & 5 & 60 & 20 & & 5 & & & $1-5$ & 10 & & & & 5 \\
\hline MAT-12 & ర్ల & 5.5 & 55 & 20 & & 5 & 5 & & & 10 & & & & 5 \\
\hline MAT-13 & 0 & 6 & 60 & 25 & & & & & $1-5$ & 5 & & & 5 & 5 \\
\hline MAT-14 & 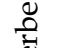 & 6.5 & 55 & 25 & & $1-5$ & & & $1-5$ & 10 & & & & 5 \\
\hline MAT-15 & $\stackrel{D}{ \pm}$ & 7 & 60 & 35 & $1-5$ & & & & & 5 & & & & \\
\hline MAT-16 & 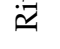 & 7.5 & 60 & 20 & & 10 & & & & 10 & & & & \\
\hline MAT-17 & $\simeq$ & 8 & 65 & 30 & 5 & & & & & & & & & \\
\hline
\end{tabular}

Three levels showing different but nearly homogeneous mineralogical compositions can be inferred from the X-ray diffraction data (Table 1): an upper level ( $2 \mathrm{~m}$ thick) of reddish clay mine tailings, an intermediate $1.5 \mathrm{~m}$ of tailings mixed with riverbed sediments, and a lower, $4 \mathrm{~m}$ level of coarse to sandy riverbed sediments. Significant amounts of pyrite, sphalerite, and galena from the mined ore deposit have been identified in all three levels, although they are higher in the mine tailings upper levels $(10 \%)$ and lower in the riverbed sediments $(5 \%)$, probably reflecting less efficient ore benefiting processes. The upper level still includes a significant proportion of the original ore. Fe-carbonates (siderite), secondary sulfates ( $\mathrm{Pb}$-jarosite, gypsum), and ore-sulfides (stannite) have also been determined in the mine tailings upper levels. It can be inferred that silicates make up 30-50 $\mathrm{wt} \%$ of the mine tailings upper level, $60-65 \mathrm{wt} \%$ of the intermediate level, and $70-95 \mathrm{wt} \%$ of the riverbed 
sediments' deeper level. Quartz, and Illite-kaolinite interstratified are the main minerals. In addition, a 5-10 wt \% greenalite $\left(\mathrm{Fe}_{2-3} \mathrm{Si}_{2} \mathrm{O}_{5}(\mathrm{OH})_{4}\right)$ content has also been estimated in the three sampled levels. Greenalite is an ore mineral associated with the hydrothermal alteration caused by intense volcanic processes. Anglesite (5-10\%) has also been identified in all samples from the three levels. The transition to the in-situ host rock was nearly sharp, with the only presence of silicates (quartz, illite-kaolinite, and chlorite. This assemblage may indicate the occurrence of hydrothermal alteration in the volcanic host rocks.

\subsection{Geochemical Characterization}

The chemical analyses confirmed the similar infilling structure and major and trace element contents for Las Matildes riverbed. The total $\mathrm{Fe}_{2} \mathrm{O}_{3}$ contents, the trace-element content, and $\mathrm{pH}$ at the different sampling depths are shown in Table 2.

The geochemistry of the sampled mine tailings and riverbed sediments matches the described mineral abundances and geophysical features well. Distribution with depth plots of these geochemical data (Figure 5) clearly shows the three-level structure previously described: tailings from the surface down to a $2.0 \mathrm{~m}$ depth, tailings mixed with riverbed deposits from 2.0 to $3.5 \mathrm{~m}$ depth, and riverbed deposits from 3.5 to $7.5 \mathrm{~m}$ depth. High contents of $\mathrm{Fe}, \mathrm{Pb}, \mathrm{Zn}$, and other heavy and transitional metals characterize the composition of all borehole samples. The total iron content ranges from 9.1 to $45.3 \mathrm{wt} \%, \mathrm{~Pb}$ from 2340 to $8640 \mu \mathrm{g} / \mathrm{g}$, and $\mathrm{Zn}$ from 897 to $12,310 \mu \mathrm{g} / \mathrm{g}$. Other trace elements also show high contents: As (up to $1620 \mu \mathrm{g} / \mathrm{g}$ ), Cd (up to $306 \mu \mathrm{g} / \mathrm{g}$ ), Cu (up to $730 \mu \mathrm{g} / \mathrm{g}$ ), and Sb (up to $236 \mu \mathrm{g} / \mathrm{g}$ ). These significant amounts are due to the nature of the deposits, composed of pyrite, sphalerite, galena, and cassiterite. [43] reported similar trace element contents in other riverbeds of the district. The metamorphic host rock (8 m depth) in turn displays significantly lower amounts of metals, as is usually the case in mine deposits [2,14]. Variation in trace element trends and iron contents are related to the textural features and mineralogical composition previously described in Section 4.3. The highest values are generally observed to be associated with the surficial level (0-2 m), representing mine tailings directly stored over the riverbed sediments. The highest $\mathrm{Ag}, \mathrm{As}, \mathrm{Fe}, \mathrm{Pb}$, and $\mathrm{Zn}$ contents are clearly located at this uppermost level (Figure 5).

The lowest contents are clearly observed in the data from the deepest borehole samples (4-7.5 m). Textural (coarse to sandy), mineralogical (silicate content), and geochemical features clearly define the deepest level as riverbed sediments. Intermediate trace elements and iron contents are correspondingly shown in the intermediate level (2.5-3.5 m depth) and are related to mixing between tailings and the riverbed sediment level. Samples from the tailings level show lower $\mathrm{pH}$ values ranging from 2.5 to 5.3 compared to the almost neutral (6.0 to 7.7) $\mathrm{pH}$ in riverbed deposits and host rock. The lowest $\mathrm{pH}$ and highest electrical conductivity (EC) values from Table 2 are also associated with the upper level, confirming the three-level structure previously described. 
Table 2. $\mathrm{Fe}_{2} \mathrm{O}_{3}$ Total and Trace Elements Content, pH, and Electrical Conductivity (EC) Values in the Las Matildes Riverbed Borehole (T+S: Tailings and Riverbed Sediments; R: Bedrock).

\begin{tabular}{|c|c|c|c|c|c|c|c|c|c|c|c|c|c|c|c|c|}
\hline Sample & & $\begin{array}{c}\text { Depth } \\
\text { (m) }\end{array}$ & $\underset{(\mu \mathrm{g} / \mathrm{g})}{\mathrm{Ag}}$ & $\begin{array}{l}\text { As } \\
(\mu \mathrm{g} / \mathrm{g})\end{array}$ & $\begin{array}{c}\text { Cd } \\
(\mu \mathrm{g} / \mathrm{g})\end{array}$ & $\begin{array}{c}\mathrm{Cr} \\
(\mu \mathrm{g} / \mathrm{g})\end{array}$ & $\begin{array}{c}\mathrm{Cu} \\
(\mu \mathrm{g} / \mathrm{g})\end{array}$ & $\begin{array}{c}\mathrm{Fe}_{2} \mathrm{O}_{3} \text { Total } \\
(\mathrm{wt} \%)\end{array}$ & $\begin{array}{c}\mathrm{Ni} \\
(\mu \mathrm{g} / \mathrm{g})\end{array}$ & $\begin{array}{c}\mathrm{Pb} \\
(\mu \mathrm{g} / \mathrm{g})\end{array}$ & $\underset{(w t \%)}{S}$ & $\begin{array}{c}S b \\
(\mu \mathrm{g} / \mathrm{g})\end{array}$ & $\begin{array}{c}\text { Sn } \\
(\mu \mathrm{g} / \mathrm{g})\end{array}$ & $\begin{array}{c}\mathrm{Zn} \\
(\mu \mathrm{g} / \mathrm{g})\end{array}$ & $\mathrm{pH}$ & $\begin{array}{c}\mathrm{EC} \\
(\mathrm{mS} / \mathrm{cm})\end{array}$ \\
\hline MAT-1 & & 0 & 33.1 & 452 & 19.1 & 40 & 350 & 39.17 & 28 & 8130 & 3.11 & 87.2 & 75 & 11220 & 4.42 & 3.20 \\
\hline MAT-2 & $\infty$ & 0.5 & 4.4 & 456 & 14.1 & 30 & 201 & 36.04 & 24 & 4130 & 4.10 & 59 & 31 & 6930 & 5.30 & 4.61 \\
\hline MAT-3 & $\fallingdotseq$ & 1 & 5.7 & 262 & 11 & b.d. & 40 & 45.26 & 15 & 5320 & 1.82 & 130 & 38 & 7230 & 4.94 & 3.44 \\
\hline MAT-4 & ] & 1.5 & 67.7 & 1620 & 306 & b.d. & 730 & 40.75 & 44 & 8640 & 16.80 & 211.5 & 122 & 12310 & 4.88 & 8.78 \\
\hline MAT-5 & & 2 & 37 & 1270 & 9.3 & 40 & 215 & 41.68 & 14 & 7270 & 3.43 & 236 & 46 & 6350 & 2.50 & 5.19 \\
\hline MAT-6 & $\infty$ & 2.5 & 2 & 27 & 5.5 & 90 & 34 & 12.88 & 47 & 7950 & 0.46 & 17.4 & 8 & 3010 & 3.83 & 1.55 \\
\hline MAT-7 & + & 3 & 3.8 & 61 & 38 & 60 & 76 & 20.47 & 46 & 7640 & 2.94 & 42.5 & 18 & 12010 & 4.51 & 3.38 \\
\hline MAT-8 & $\mapsto$ & 3.5 & 4.3 & 26 & 133 & 60 & 69 & 9.11 & 86 & 2340 & 3.38 & 18.6 & 9 & 9870 & 6.38 & 2.53 \\
\hline MAT-9 & $\infty$ & 4 & 1.7 & 42 & 8.4 & 70 & 169 & 15.38 & 50 & 3640 & 0.45 & 21 & 29 & 4680 & 6.08 & 1.85 \\
\hline MAT-10 & $\vec{E}$ & 4.5 & 1.7 & 48 & 3.6 & 70 & 110 & 11.80 & 42 & 2720 & 0.15 & 25 & 28 & 1140 & 6.28 & 0.63 \\
\hline MAT-11 & $\Xi$ & 5 & 2.1 & 38 & 3.2 & 60 & 89 & 9.78 & 32 & 2450 & 0.16 & 19.7 & 21 & 897 & 6.51 & 0.58 \\
\hline MAT-12 & ర్రు & 5.5 & 1.6 & 51 & 10.5 & 50 & 120 & 27.37 & 41 & 5870 & 0.34 & 39.7 & 19 & 3890 & 6.58 & 1.23 \\
\hline MAT-13 & 0 & 6 & 1.9 & 92 & 6.9 & 60 & 126 & 22.82 & 42 & 5960 & 0.23 & 44.8 & 20 & 1980 & 6.20 & 1.33 \\
\hline MAT-14 & 䒕 & 6.5 & 1.2 & 79 & 9.9 & 80 & 87 & 14.54 & 43 & 4210 & 0.17 & 32.6 & 44 & 1240 & 5.45 & 0.81 \\
\hline MAT-15 & $\stackrel{\vec{D}}{ \pm}$ & 7 & 1.2 & 51 & 11.9 & 80 & 98 & 13.39 & 47 & 3460 & 0.14 & 21.5 & 234 & 1050 & 4.55 & 0.93 \\
\hline MAT-16 & $\ddot{\sim}$ & 7.5 & 14.6 & 147 & 9.3 & 50 & 298 & 30.77 & 20 & 6770 & 0.27 & 37.5 & 1190 & 994 & 7.74 & 0.26 \\
\hline MAT-17 & $\simeq$ & 8 & 0.8 & b.d. & 3.8 & 80 & 1 & 9.08 & 40 & 888 & 0.02 & 8.3 & 6 & 764 & 7.75 & 0.15 \\
\hline
\end{tabular}

b.d. below detection. 

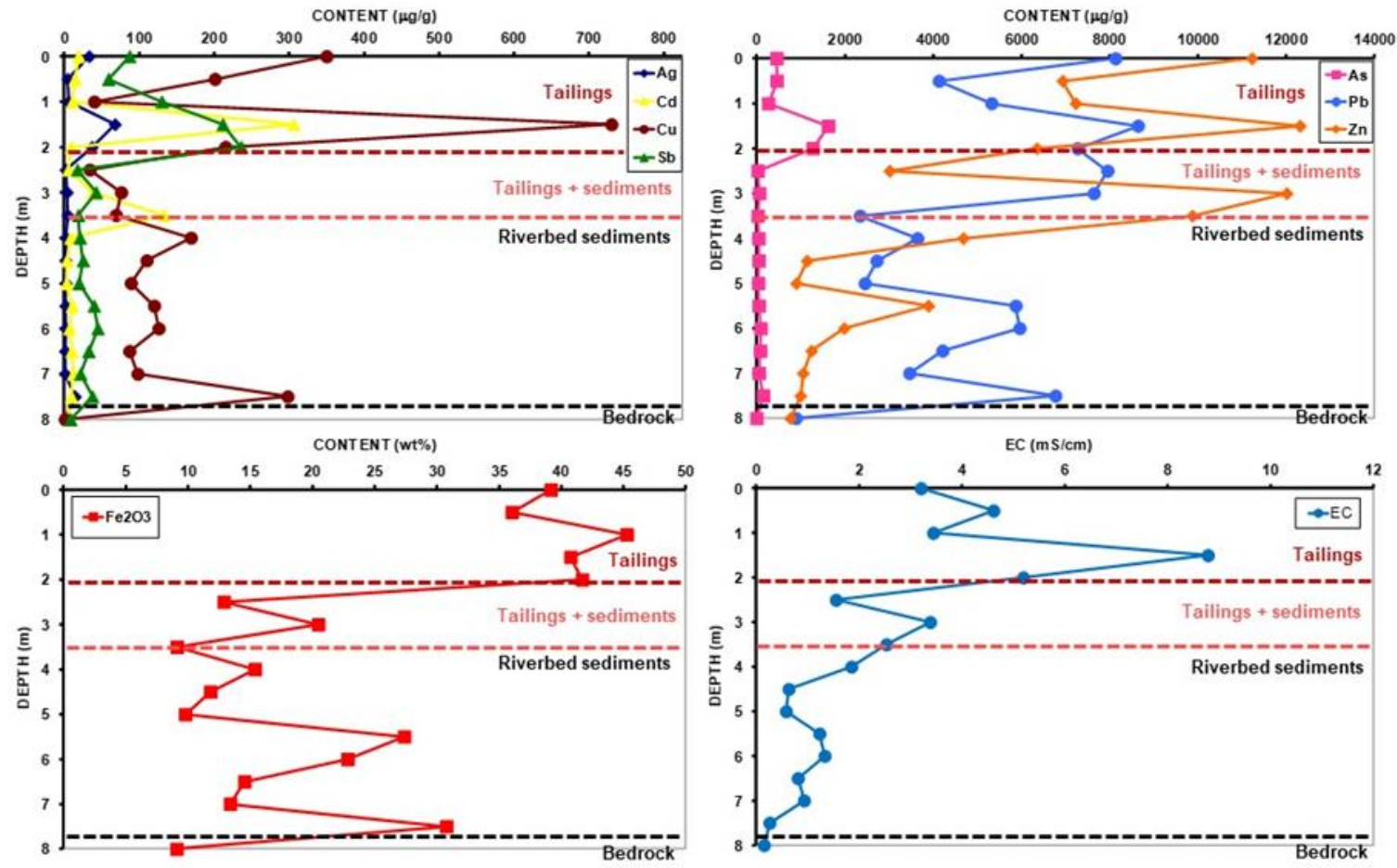

Figure 5. Distribution-with-depth profiles for total ferric iron and trace element concentrations from Las Matildes borehole samples.

The dendrogram (cluster membership) of metals ( $\mathrm{Ag}, \mathrm{Sb}, \mathrm{Fe}, \mathrm{Cd}, \mathrm{Cu}, \mathrm{Pb}, \mathrm{Zn}, \mathrm{Sn})$ and $\mathrm{As}$ in the borehole samples (Figure 6a) is consistent with the metallic signature of the ore in the district ( $\mathrm{Pb}-\mathrm{Zn}-\mathrm{Cd}-\mathrm{Cu}-\mathrm{Sn}$, and Ag-As-Sb-Fe [20,21]), with As being mainly related to Sb (tetrahedrite-tenantite mineral group). The Ag- $\mathrm{Pb}-\mathrm{Cd}-\mathrm{Zn}$ signature is strongly defined due to the source of the minerals: the Emilia mine. $[2,13,14]$ reported the same geochemical behavior in other works on similar mine ponds.

The cluster analysis of samples from the Las Matildes borehole shows the existence of two groups defining two main associations: mine tailings (MT) and mine tailings mixed with riverbed deposits (MTR) (Figure 6b). The MT association displays the uppermost $2 \mathrm{~m}$ thick level, characterized by the presence of ore minerals galena and sphalerite (with lower amounts of pyrite, stannite, jarosite, and siderite). The MTR association represents the mine tailings mixed with riverbed deposits and is characterized by higher amounts of silicates (quartz, illite-kaolinite, chlorite, and greenalite) and anglesite, with sulphide abundance decreasing at depth.

The highest trace element values observed in the upper mine tailings level are related to inefficient metallurgical processing of the benefited ore during the working years. High trace elements and iron contents in mine tailings have been obtained by the authors in similar deposits from Cartagena-La Unión [14], Mazarrón [2], Valle de Alcudia [13,44], and Iberian Pyrite Belt districts [11,12]. Significant metal amounts at the deepest level (riverbed sediments) is noticeable, probably related to the strong annual stormy episodes in this Mediterranean coastal area. Significant flash flood phenomena have also been described affecting abandoned mine deposits and structures [14,45]. 

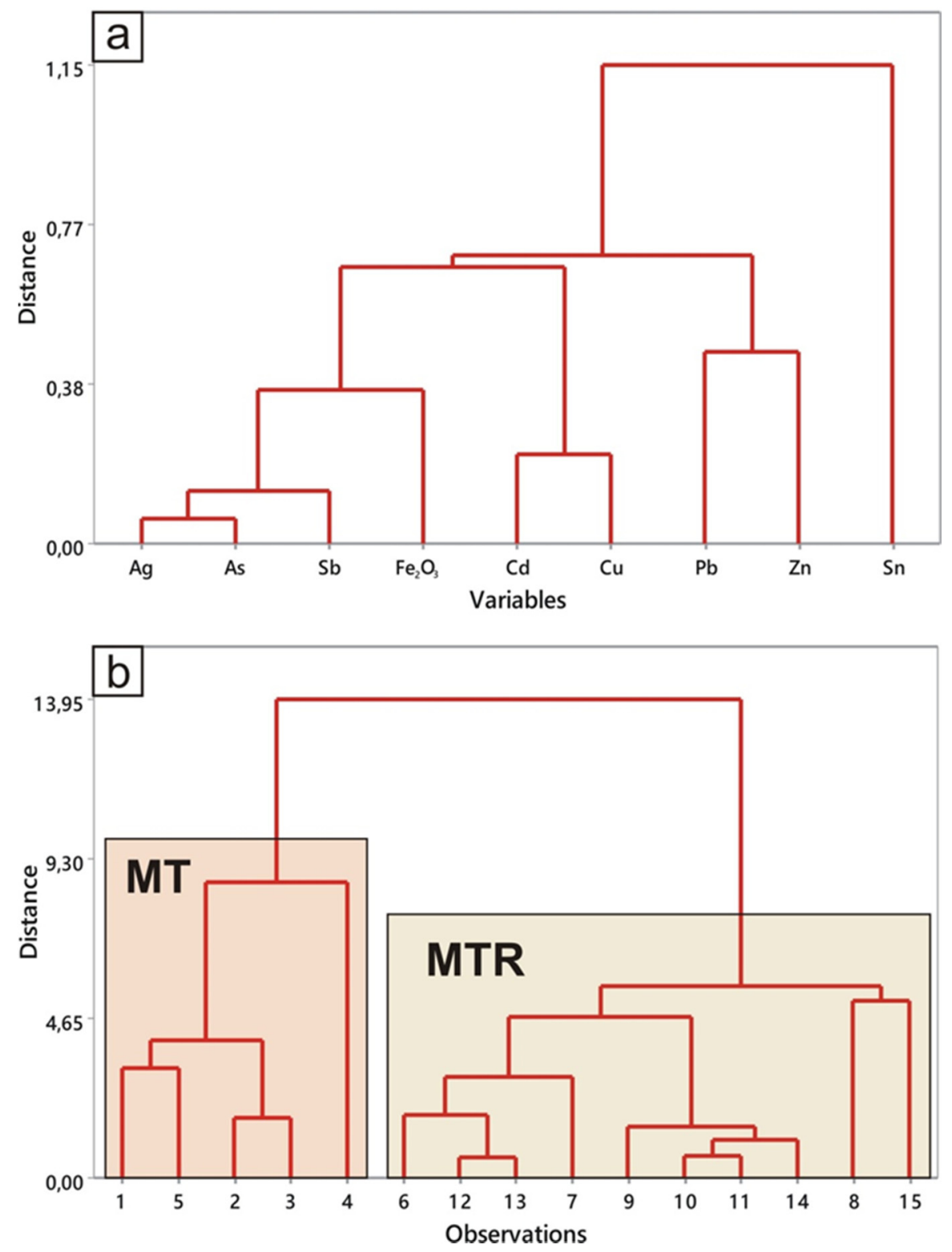

Figure 6. (a) Dendrogram (distance: simple) of metals from all borehole samples; (b) dendrogram (distance: Euclidean) defining two main associations of samples: mine tailings (MT) and mine tailings mixed with riverbed deposits (MTR).

\subsection{Environmental Concerns}

Potential environmental concerns are usually classified into three broad categories: (i) human health risks; (ii) ecosystem risks; and (iii) physical hazards. Physical hazards (open pits, open shafts, instable ponds) are broadly found in the Cartagena-La Unión district. Ecosystem and human risks have been assessed using the Geoaccumulation Index $\left(\mathrm{I}_{\text {geo }}\right)$. $\mathrm{I}_{\text {geo }}$ enables the assessment of contamination of sediments by comparing current and pre-industrial concentrations of heavy metals [46]. It is expressed as $I_{\text {geo }}=\log 2 \mathrm{Cn} / 1.5 \mathrm{Bn}$, where $\mathrm{Cn}$ is the concentration of an element in the sediment sample and $\mathrm{Bn}$ is the background concentration of that element in the Earth's crust, according to [47]. The factor 1.5 is usually used to address possible variations due to lithogenic effects. [46] defined six possible ranges: uncontaminated $\left(\mathrm{I}_{\text {geo }} \leq 0\right)$, uncontaminated to moderately contaminated $\left(0<\mathrm{I}_{\text {geo }}<1\right)$, moderately contaminated $\left(1<\mathrm{I}_{\text {geo }}<2\right)$, moderately to strongly contaminated $\left(2<\mathrm{I}_{\text {geo }}<3\right)$, strongly contaminated $\left(3<\mathrm{I}_{\text {geo }}<4\right)$, strongly to extremely contaminated $\left(4<\mathrm{I}_{\text {geo }}<5\right)$, and extremely contaminated ( $\left.\mathrm{I}_{\text {geo }}>5\right)$. Metal and As $I_{\text {geo }}$ values in borehole samples were calculated and are shown in Figure 7. As expected 
from contents in Table 2 and Figure 5, most trace elements (As, Cd, Pb, Sb, and $\mathrm{Zn}$ ) show strong to extreme contamination in all borehole samples. Tailings samples (0-2 $\mathrm{m}$ depth) are plotted in the extremely contaminated range $\left(\mathrm{I}_{\text {geo }}>5\right)$, whereas tailings mixed with riverbed sediments and riverbed sediments show strongly to extremely contaminated ranges. $\mathrm{Cu}$ and $\mathrm{Sn}$ show moderate to uncontaminated values, and Ag is classified as a non-pollutant due to low $\mathrm{I}_{\text {geo }}$ values. The present study reveals the significant contamination of riverbed sedimentary deposits from mine tailings, not only at the surface, but also at depth. Martínez-Martínez, et al [48] calculated similar Igeo values for tailings ponds and natural soils from the southern slope of the mine district. The same behavior has also been observed by the authors in similar abandoned Spanish mine sites: Iberian Pyrite Belt [11,12], San Quintín mining group [13], and Mazarrón district [2].

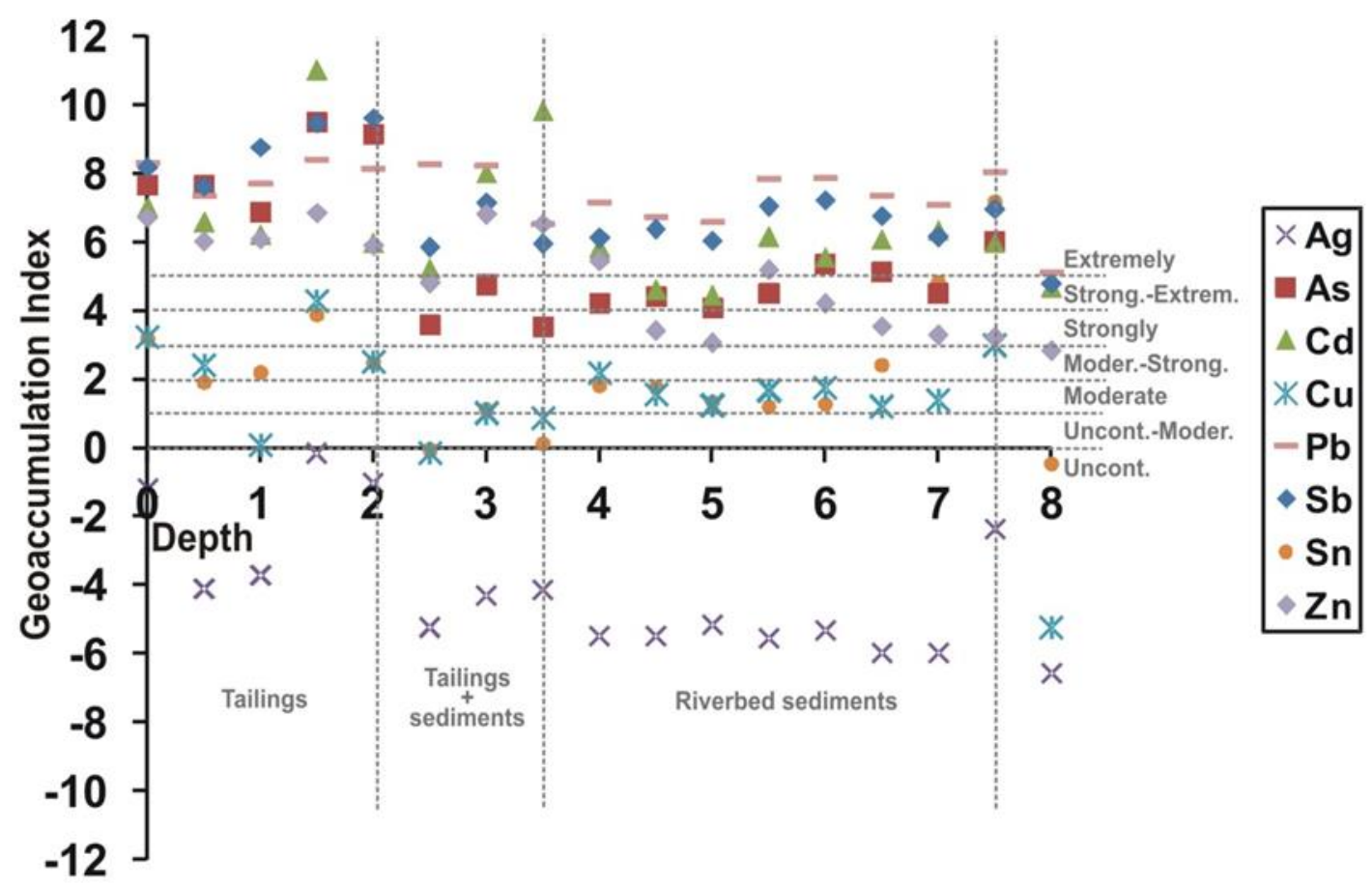

Figure 7. Variation at depth of the Geoaccumulation Index $\left(\mathrm{I}_{\text {geo }}\right)$ of metals and for the borehole samples.

Mineral wastes, intensive agricultural activities, and the population of the Campo de Cartagena area (400,000 people; 600,000 people in summertime) overlap within the district. Cultivated lands $(50,000$ hectares of horticultural irrigated crops) are located in the adjacent areas downstream of the Cartagena-La Unión mine district (Figure 1). Thus, dispersion of metal-rich particles to agricultural soils surrounding the mine tailings has revealed an important hazard for the environment. This is especially significant in the Mediterranean context, where river courses remain dry for a 5-10-year period due to the semi-arid climate of SE Spain, except when sporadic and torrential rainfall occurs. Since all mining activities ceased in 1991, potentially toxic elements from the mine tailings are being released by water and aeolian erosion. Thus, intense water erosion removes and transports particles from tailings during strong stormy episodes, and aeolian erosion induces the fine particle dispersion. In the study area, the aeolian dispersion of tailings could be considered negligible because of low to moderate wind velocity (2-4 m/s) [49]. The most important erosion mechanism in the Cartagena-La Unión mine district is hydraulic erosion by stormy episodes inducing erosive flash flood phenomena. As a result, very significant amounts of abandoned mine tailings from the Descargador mine pond have been eroded (Figure 2), transported, and re-deposited in El Miedo riverbed, and finally, in the Mar Menor. 
There, 100,000 people usually spend the summer in the surrounding touristic areas. There is a perceptible environmental concern, as the sediments from the Mar Menor lagoon are highly polluted by heavy metals transferred from the Cartagena-La Unión mine district [50]. Reference [51] measured concentration values of $\mathrm{Zn}(>3500 \mu \mathrm{g} / \mathrm{g})$ and $\mathrm{Pb}(\approx 3000 \mu \mathrm{g} / \mathrm{g}) 48$ and 43 times higher, respectively, than those in the Mediterranean Sea reference sediment sample. Erena et al. [52] develops an operational system to monitor the evolution and variability of the turbidity and chlorophyll-a levels through the joint use of remote sensing techniques (Operational Land Imager and SPOT images) and in situ data.

Together with the use of geochemical data to infer environmental concerns, as previously stated, the geophysical characterization of abandoned mine deposits constitutes a useful, cheap, and fast acquisition technique to obtain complementary information. The use of ERI allows obtaining crucial information necessary for a proper evaluation, such as the thickness and internal structure of the deposits, the occurrence or not of AMD flows that would affect both the surface and groundwater, and the computation of the volume of potentially hazardous material stored in the mine deposits. The latter constitutes essential information in the case where reclamation and/or remediation of the deposits is envisaged. Urgent work must be clearly focused on (i) gaining in-depth knowledge of hydraulic erosion and dispersion, (ii) permanent monitoring of toxic element contents in waters flowing towards the Mar Menor, (iii) remediating resulting soils, and (iv) re-analyzing agricultural practices from an ecotoxicological point of view.

The inputs that can be highlighted compared to previous works are (i) a more detailed geochemical and mineralogical characterization of tailings and riverbed sediments from surface to bedrock samples (borehole), not only from surficial ones; (ii) the assessment of contamination of riverbed sediments estimated using the Geoaccumulation Index; (iii) application of the ERI method in this area to obtain more detailed information about the internal structure of the deposits and bedrock; (iv) the temporal evolution of the mining landscape of La Unión area by the use of orthoimages covering the last 70 years, the most active mining period.

\section{Conclusions}

The joint use of landscape evolution studies, and geophysical, mineralogical, and geochemical techniques has been confirmed as providing a complete environmental characterization of abandoned mine sites, also allowing estimations of the pollution grade and the extent of affected zones. The natural landscape to the $\mathrm{E}$ of La Unión town has been deeply modified by the mining activity. The former summits of Sierra de Cartagena-La Unión disappeared while huge depressions were created due to mineral extraction in open-pit mines. Rock, molten slags, and tailings deposits accumulated in ephemeral riverbeds and foothills, altering the drainage pattern and burying the fluvial channels. Nearly one fourth of the studied territory is overlaid by mining wastes. These transformations are evidenced in the geophysical, mineralogical, and geochemical results obtained in this work. At the Descargador mine site, geophysical surveys and mineralogical-geochemical data from borehole samples provide similar results. For the mine pond infilling, ERI surveys have allowed imaging a 5 to $8 \mathrm{~m}$ thick three-unit sequence with low resistivity values, in good agreement with the alternating layers of clay and sandy texture seen at the available outcrop in the area. The geometry of the mine pond boundary is clearly imaged at depth due to the high resistivity values and high dielectric permittivity contrast of the metasediments bounding the mine pond.

At the dry riverbed site, a $\sim 4$-m-thick upper unit of low resistivity values and a $\sim 3.5-4$-m-thick lower unit of higher resistivity values were distinguished and respectively correlated with surficial mine tailings and underlying riverbed sediments. The highest resistivity values correspond to the metasediments located below the two previous units. These results are in good agreement with borehole data. Significant amounts of pyrite, sphalerite, and galena were identified in the borehole samples, and are much more concentrated in the tailings upper levels than in the sediment's lower ones. The alluvial material from the riverbed showed significant toxic metal contents ( $\mathrm{As}, \mathrm{Cd}, \mathrm{Fe}, \mathrm{Pb}$, and $\mathrm{Zn}$ ) as well. Mineralogical and geochemical data have proved the important removal of pollutants by water 
erosion from mine waste deposits that finally reach the water courses. In fact, rock and metallurgical wastes alter the drainage pattern and bury the headwaters of ephemeral channels. The strongly seasonal character of the Mediterranean climate, which concentrates almost all the annual rainfall in heavy, episodic storms, increases the potential hazard in this area. Thus, strong water erosion and the transport of extremely contaminated tailings $\left(\mathrm{I}_{\text {geo }}\right)$ affect the agricultural soils and the Mar Menor, one of the most important touristic destinations in SE Spain. Both reclamation of the Cartagena-La Unión mining district and intensive monitoring of waters and soils are highly recommended to recover one of the most problematic yet tourist-popular areas of SE Spain from the environmental point of view.

Author Contributions: Data curation, T.M.-C. and D.G.-O.; Formal analysis, S.M.-V., C.d.I.-S.J. and J.L.; Investigation, T.M.-C. and P.M.-P.; Methodology, D.G.-O.; Writing-original draft, T.M.-C., D.G.-O. and S.M.-V.; Writing-review \& editing, P.M.-P., C.d.I.-S.J., J.L. and Á.F. All authors have read and agreed to the published version of the manuscript.

Funding: This work has been accomplished within the framework of project URJC-CM-2006-CET-0636 funded by Comunidad de Madrid and Universidad Rey Juan Carlos.

Acknowledgments: We would like to thank the three anonymous reviewers and the editor for their suggestions and comments that considerably improved the quality of the paper.

Conflicts of Interest: The authors declare no conflict of interest.

\section{References}

1. Robles-Arenas, V.M.; Rodríguez, R.; García, C.; Manteca, J.I.; Candela, L. Sulphide-mining impacts in the physical environment: Sierra de Cartagena-La Unión (SE Spain) case study. Environ. Geol. 2006, 51, 47-64. [CrossRef]

2. Martín-Crespo, T.; Gómez-Ortiz, D.; Martínez-Pagán, P.; de Ignacio-San José, C.; Martín-Velázquez, S.; Lillo, J.; Faz, A. Geoenvironmental characterization of riverbeds affected by mine tailings in the Mazarrón district (Spain). J. Geochem. Explor. 2012, 119-120, 6-16. [CrossRef]

3. Morris, B.; Shang, J.; Howarth, P.; Witherly, K. Application of Remote Sensing and Airborne Geophysics to Mine Tailings Monitoring. In Copper Cliff, Ontario. Symposium on the Application of Geophysics to Engineering and Environmental Problems; Environmental \& Engineering Geophysical Society: Denver, CO, USA, 2002. [CrossRef]

4. Smith, B.D.; McDougal, R.R.; McCafferty, A.E.; Deszcz-Pan, M.; Yager, D.B. Helicopter Electromagnetic and Magnetic Survey of the Upper Animas River Watershed; Application to Abandoned Mine Land Studies. In Proceedings of the 17th EEGS Symposium on the Application of Geophysics to Engineering and Environmental Problems, Colorado Springs, CO, USA, 22-26 February 2004; pp. 140-155.

5. Booterbaugh, A.P.; Bentley, L.R.; Mendoza, C.A. Geophysical Characterization of an Undrained Dyke Containing an Oil Sands Tailings Pond, Alberta, Canada. J. Environ. Eng. Geoph. 2015, 20, 303-317. [CrossRef]

6. Haegeman, W.; Van Impe, W.F. Characterization of Disposal Sites from Surface Wave Measurements. J. Environ. Eng. Geophys. 1999, 4, 27-33. [CrossRef]

7. Lghoul, M.; Teixidó, T.; Peña, J.A.; Hakkou, R.; Kchikach, A.; Guérin, R.; Jaffal, M.; Zouhri, L. Electrical and Seismic Tomography Used to Image the Structure of a Tailings Pond at the Abandoned Kettara Mine, Morocco. Mine Water Environ. 2012, 31, 53-61. [CrossRef]

8. Loke, M.H.; Chambers, J.E.; Rucker, D.F.; Kuras, O.; Wilkinson, P.B. Recent developments in the direct-current geoelectrical imaging method. J. Appl. Geophys. 2013, 95, 135-156. [CrossRef]

9. Martínez, J.; Rey, J.; Hidalgo, M.C.; Garrido, J.; Rojas, D. Influence of measurement conditions on the resolution of electrical resistivity imaging: The example of abandoned mining dams in the La Carolina District (Southern Spain). Int. J. Min. Process 2014, 133, 67-72. [CrossRef]

10. Acosta, J.A.; Martínez-Pagán, P.; Martínez-Martínez, S.; Faz, A.; Zornoza, R.; Carmona, D.M. Assessment of environmental risk of reclaimed mining ponds using geophysics and geochemical techniques. J. Geochem. Explor. 2014, 147, 80-90. [CrossRef] 
11. Martín-Crespo, T.; de Ignacio-San José, C.; Gómez-Ortiz, D.; Martín-Velázquez, S.; Lillo, J. Monitoring study of the mine pond reclamation of Mina Concepción, Iberian Pyrite Belt (Spain). Environ. Earth Sci. 2010, 54, 1275-1284. [CrossRef]

12. Martín-Crespo, T.; Martín-Velázquez, S.; Gómez-Ortiz, D.; de Ignacio-San José, C.; Lillo, J. A geophysical and geochemical characterization of sulphide mine ponds at the Iberian Pyrite Belt (Spain). Water Air Soil Pollut. 2011, 217, 287-405. [CrossRef]

13. Martín-Crespo, T.; Gómez-Ortiz, D.; Martínez-Pagán, P.; Martín-Velázquez, S.; Esbrí, J.M.; de Ignacio-San José, C.; Sánchez-García, M.J.; Montoya-Montes, I.; Martín-González, F. Abandoned mine tailings in cultural itineraries: Don Quijote Route (Spain). Eng. Geol. 2015, 197, 82-93. [CrossRef]

14. Martín-Crespo, T.; Gómez-Ortiz, D.; Martín-Velázquez, S.; Martínez-Pagán, P.; de Ignacio-San José, C.; Lillo, J.; Faz, A. Geoenvironmental characterization of unstable abandoned mine tailings combining geophysical and geochemical methods (Cartagena-La Union). Eng. Geol. 2018, 232, 135-146. [CrossRef]

15. Martín-Crespo, T.; Gómez-Ortiz, D.; Martín-Velázquez, S. Geoenvironmental Characterization of Sulfide Mine Tailings. In Applied Geochemistry with Case Studies on Geological Formations, Exploration Techniques and Environmental Issues; Mazadiego, F.L., Barrio-Parra, F., Izquierdo-Díaz, M., Eds.; IntechOpen: London, UK, 2020; pp. 1-26. [CrossRef]

16. Montoya-Montes, I.; Cano-Bermejo, I.; Sánchez-García, M.J.; de Ignacio-San José, C.; Martín-Velázquez, S.; Gómez-Ortiz, D.; Martín-Crespo, T.; Martín-González, F. Formación de cuerpos dunares a partir de lodos mineros: Mina de San Quintín (Ciudad Real, España). Geotemas 2012, 13, 1487-1490.

17. Martín Duque, J.F.; Zapico, I.; Oyarzun, R.; López García, J.A.; Cubas, P. A descriptive and quantitative approach regarding erosion and development of landforms on abandoned mine tailings: New insights and environmental implications from SE Spain. Geomorphology 2015, 239, 1-16. [CrossRef]

18. Villar, J.B.; Egea, P.; Fernández, J.C. La Minería Murciana Contemporánea (1930-1985); IGME: Madrid, Spain, $1991 ; 256 \mathrm{p}$.

19. IGME. Inventario Nacional de Depósitos de Lodos; Published database; IGME (Instituto Geológico y Minero de España): Madrid, Spain, 2002.

20. López García, J.A. Estudio Mineralógico, Textural y Geoquímico de Las Zonas de Oxidación de Los Yacimientos de Fe-Pb y Zn de la Sierra de Cartagena (Murcia). Ph.D. Dissertation, Universidad Complutense, Madrid, Spain, 1985.

21. Sanmartí, L.; Gaya, A.; Molina, C.; Amores, S.; Villanovade-Benavent, C.; Torró, L.; Melgarejo, J.C.; Manteca, J.I. The mineral association in the Emilia and Brunita Pb-Zn-Ag-(Sn) deposits, La Unión, Murcia (Spain). In Proceedings of the 2th SGA Biennial Meeting, Uppsala, Sweden, 12-15 August 2013.

22. Martín-Rosales, W.; Pulido-Bosch, A.; Vallejos, Á.; Gisbert, J.; Andreu, J.M.; Sánchez-Martos, F. Hydrological implications of desertification in southeastern Spain. Hydrolog. Sci. J. 2007, 52, 1146-1161. [CrossRef]

23. Robles-Arenas, V.M.; Candela, L. Hydrogeological conceptual model characterisation of an abandoned mine site in semiarid climate. The Sierra de Cartagena-La Unión (SE Spain). Geol. Acta 2010, 8, 235-248.

24. SIAM. Sistema de Información Agraria de Murcia; SIAM: Murcia, Spain, 2017; Available online: http://siam. imida.es (accessed on 28 September 2017).

25. Mouzo Pagán, R. Crónicas Mineras de Rogelio Mouzo Pagán. 2012. Available online: http://cronicasmineras. blogspot.com.es/2012/10/inundaciones-en-la-sierra-minera-de.html (accessed on 14 April 2020).

26. Kearey, P.; Brooks, M.; Hill, I. An Introduction to Geophysical Exploration; Blackwell Science: Oxford, UK, 2002; $272 \mathrm{p}$.

27. Revil, A.; Karaoulis, M.; Johnson, T.; Kemna, A. Review: Some low-frequency electrical methods for subsurface characterization and monitoring in hydrogeology. Hydrogeol. J. 2012, 20, 617-658. [CrossRef]

28. Reynolds, J.M. An Introduction to Applied and Environmental Geophysics, 2nd ed.; John Wiley \& Sons: New York, NY, USA, 2011; 710p.

29. Telford, W.M.; Geldart, L.P.; Sheriff, R.E.; Keys, D.A. Applied Geophysics; University Press: Cambridge, UK, 1990; 770p.

30. Janik, M.; Krummel, H. Geoelectrical methods: 2D measurements. In Groundwater Geophysics: A Tool for Hydrogeology; Kirsch, R., Ed.; Springer: Heidelberg, Germany, 2009; pp. 109-117.

31. Loke, M.H.; Acworth, I.; Dahlin, T. A comparison of smooth and blocky inversion method in 2D electrical imaging surveys. Explor. Geophys. 2003, 34, 182-187. [CrossRef] 
32. Buselli, G.; Hwang, H.S.; Lu, K. Minesite groundwater contamination mapping. Explor. Geophys. 1998, 29, 296-300. [CrossRef]

33. Campbell, D.L.; Fitterman, D.V. Geoelectrical methods for investigating mine dumps. In Proceedings of the Fifth International Conference on Acid Rock Drainage (ICARD2000), Denver, CO, USA, 21-24 May 2000; Society for Mining, Metallurgy, and Exploration, Inc.: Englewood, CO, USA, 2000; pp. 1513-1523.

34. Yuval, D.; Oldenburg, W. DC resistivity and IP methods in acid mine drainage problems: Results from the Copper Cliff mine tailings impoundments. J. Appl. Geophys. 1996, 34, 187-198. [CrossRef]

35. Niederleithinger, E.; Kruschwitz, S. Multi-channel Spectral Induced Polarization (SIP) measurements on tailings dams. In Near Surface Meeting; EAGE: Palermo, Italy, 2005.

36. Martínez-Pagán, P.; Faz, A.; Aracil, E.; Arocena, J.M. Electrical resistivity imaging revealed the spatial properties of mine tailings ponds in the Sierra Minera of Southeast Spain. J. Eng. Environ. Geophys. 2009, 14, 63-76. [CrossRef]

37. Gómez-Ortiz, D.; Martín-Velázquez, S.; Martín-Crespo, T.; De Ignacio-San José, C.; Lillo-Ramos, J. Application of electrical resistivity tomography to the environmental characterization of abandoned massive sulphide mine ponds (Iberian Pyrite Belt, SW Spain). Near. Surf. Geophys. 2010, 8, 65-74. [CrossRef]

38. Martínez, J.; Hidalgo, M.C.; Rey, J.; Garrido, J.; Kohfahl, C.; Benavente, J.; Rojas, D. A multidisciplinary characterization of a tailings pond in the Linares-La Carolina mining district, Spain. J. Geochem. Explor. 2016, 162, 62-71.

39. Cortada, U.; Martínez, J.; Rey, J.; Hidalgo, M.C.; Sandoval, S. Assessment of tailings pond seals using geophysical and hydrochemical techniques. Eng. Geol. 2017, 227, 59-70. [CrossRef]

40. US EPA. Clean Water Act; Section 503; No. 32; Environmental Protection Agency: Washington, DC, USA, 1993; Volume 58.

41. IGN. Topographic Map of Cartagena, 977, 1:50.000, 1st ed.; IGN: Madrid, Spain, 1945.

42. IGN. Topographic Map of Cartagena, 977, 1:50.000, 2nd ed.; IGN: Madrid, Spain, 2018.

43. Conesa-Alcaraz, H.; Jiménez-Cárceles, F.J.; María-Cervantes, A.; González-Alcaraz, M.N.; Egea-Nicolás, C.; Álvarez-Roger, J. Heavy metal contamination caused by mining activities in the Mar Menor lagoon (SE Spain). In Heavy Metal Sediments; Lucía, H.S., Ed.; Nova Science Publishers: New York, NY, USA, 2012; pp. 115-134.

44. Gómez-Ortiz, D.; Martín-Crespo, T.; Esbrí, J.M. Geoenvironmental characterization of the San Quintín mine tailings, Ciudad Real (Spain). DYNA 2010, 161, 131-140.

45. Oyarzun, R.; Lillo, J.; López-García, J.A.; Esbrí, J.M.; Cubas, P.; Llanos, W.; Higueras, P. The Mazarrón $\mathrm{Pb}-(\mathrm{Ag})-\mathrm{Zn}$ mining district (SE Spain) as a source of heavy metal contamination in a semiarid realm: Geochemical data from mine wastes, soils, and stream sediments. J. Geochem. Explor. 2011, 109, 113-124. [CrossRef]

46. Müller, G. Index of geoaccumulation in sediments of the Rhine River. Geojournal 1969, 2, 108-118.

47. Taylor, S.R.; McLennan, S.M. The geochemical evolution of the continental crust. Rev. Geophys. 1995, 33, 241-265. [CrossRef]

48. Martínez-Martínez, S.; Acosta, J.A.; Faz Cano, A.; Carmona, D.M.; Zornoza, R.; Cerca, C. Assessment of the lead and zinc contents in natural soils and tailings ponds from the Cartagena-La Unión mining district, SE Spain. J. Geochem. Explor. 2013, 124, 166-175. [CrossRef]

49. Ministerio de Medio Ambiente. Rosas de Viento (1971-2000); CD-Rom: Madrid, Spain, 2005.

50. Marín-Guirao, L.; Cesar, A.; Marín, A.; Vita, R. Assessment of sediment metal contamination in the Mar Menor coastal lagoon (SE Spain): Metal distribution, toxicity, bioaccumulation and benthic community structure. Cienc. Mar. 2005, 31, 413-428.

51. Dassenakis, M.; García, G.; Diamantopoulou, E.; Girona, J.D.; García-Marin, E.M.; Filippi, G.; Fioraki, V. The impact of mining activities on the hypersaline Mar Menor lagoon. Desalin. Water Treat. 2010, 13, $282-289$. [CrossRef]

52. Erena, M.; Domínguez, J.A.; Aguado-Giménez, F.; Soria, J.; García-Galiano, S. Monitoring coastal lagoon water quality through remote sensing: The Mar Menor as a case study. Water-Sui 2019, 11, 1468. [CrossRef] 